
\title{
25 Research Square \\ Quality of life in the Elders has not Been Regarded as much as their Life Span: A Population-Based Study From Iran
}

\section{Behnam Honarvar}

Health Policy Research Center, Institute of Health, Shiraz University of Medical Sciences, Shiraz, Iran

\section{Elahe Khaksar}

Health Policy Research Center, Institute of Health, Shiraz University of Medical Sciences, Shiraz, Iran

Pedram Keshavarz ( $\square$ keshavarz.p2390@gmail.com )

Shiraz University of Medical Sciences https://orcid.org/0000-0001-5374-5514

\section{Yasaman Movahednejad}

Health Policy Research Center, Institute of Health, Shiraz University of Medical Sciences, Shiraz, Iran

Morteza Banakar

Health Policy Research Center, Institute of Health, Shiraz University of Medical Sciences, Shiraz, Iran

\section{Research}

Keywords: Quality of life, Life expectancy, Elder, LIEPAD, Core, Moderator

Posted Date: April 6th, 2020

DOI: https://doi.org/10.21203/rs.3.rs-19225/v1

License: (c) (i) This work is licensed under a Creative Commons Attribution 4.0 International License. Read Full License 


\section{Abstract}

Background Quality of life (QOL) in the elderly people was not addressed as much as their life expectancy. Aim The aim of this study was to evaluate the QOL in the elders. Method In this crosssectional study, the elders were selected by multi-stage cluster random sampling from health centerscovered population of Shiraz, Iran and interviewed individually. The Persian version of the Leiden-Padua (LIEPAD) questionnaire, consisting of core components (CCQOL) and moderators (MQOL) of QOL was used. SPSS software (version 25) was applied for data analysis. Results The mean age of 386 participants was $68.12 \pm 6.24$ years. The female to male ratio was 1.1 and $350(90.7 \%)$ educated up to 12 years. The mean score of QOL (sum of CCQOL and MQOL) was $83.67 \pm 13.75$ (out of 147); consisting of 27 (6.9\%) participants with low, $316(81.8 \%)$ with moderate and $43(11 \%)$ with high level of QOL. The mean scores of CCQOL and MQOL were $70.68 \pm 9.42$ (out of 93) and $14.14 \pm 2.46$ (out of 54), respectively. Multivariable analysis showed that sleep disorder $(B=-0.15)$, osteoporosis $(B=-0.14)$, female gender $(B=-0.13)$, and not being the source of family income $(B=-0.13)$ were significantly and inversely associated with QOL, while sleep disorder, facing to violence, female gender, migraine, psychological disease and not being the source of family income were inversely associated with CCQOL. Sexual problem, facing to violence, not having supplementary insurance, inability to walk and migraine had a significant and an inverse correlation with MQOL. Conclusion Four out of five elders in the Shiraz region have moderate level of QOL, while the elder females and the elders with chronic diseases, as well as the elders who are not the source of their family income had a lower level of QOL. Quality of life in the elders can be improved through an integrated care program in the health centers.

\section{Introduction}

There are growing numbers of older people worldwide [1], since their life expectancy has markedly increased over the past century, mainly due to public health improvements [2]. By 2050, the world's population aged 60 years and older is expected to reach 2 billion, up from 900 million in $2015[3,4]$. Similarly, it is estimated that the population of Iran will increase to 90 million with an increasing rate about 30\% till 2050 [5]. Besides life expectancy, maintaining quality of life (QOL) is also important as it was emphasized by World Health Organization (WHO) and many other institutions [6, 7]. Therefore, it is necessary to implement strategies for healthy and active aging by focusing improvement of QOL in this group of people [8]. The quality of life (QOL) is a broad-ranging concept which is affected in a complicated manner by a person's physical health, psychological state, personal beliefs, social relationships and their relationship to salient features of their environment [9]. The QOL among older people tends to decline as age increased, partially due to their poorer health than younger people that is associated with impaired mobility, lack of social activities, depression, and low performance in the activities of daily life [10]. Therefore, the objective of this study was to investigate the QOL-associated factors and especially modifiable ones to prevent their negative health outcomes.

\section{Method}


This cross-sectional study was performed in 2019 in Shiraz, capital city of Fars Province located in the southwest of Iran. Considering the QOL level of $78 \%$ in the elders [11], $95 \%$ level of confidence and $5 \%$ error, the sample size was calculated 264 using the Cochran formula. However, the final sample size reached to 381 considering the effect size of 1.2 (due to multistage sampling) and drop out of $20 \%$, Shiraz with a population around 2 million that more than 172000 of them are elders was divided into three main health networks. Each health network consisted of several health centers. About $95 \%$ of the older adults in Shiraz are under the coverage of these networks. First, the sample size in each network was determined proportionally according to their elderly population. Then, three health centers were selected by random sampling in each health network. The participants were selected based on the proportion of registered elders in each health center by systematic random sampling from existed family records. One elder was chosen from each family. Then, selected elders (or their family members) were contacted by phone and they were informed about the study. The elders, who agreed to the study conditions were invited to come to the Shiraz University of Medical Sciences (SUMS) affiliated Motahari Clinic (Shiraz, Iran), based on their convenience in one of the offered dates. The elders who had Alzheimer's disease were excluded from this study as this issue was indicated by their roommate in the first phone call.

A face-to-face and in personal interview was done with each of the elders by the same gender interviewer in the clinic. Demographic, socioeconomic and medical backgrounds of interviewees were asked of them or their companions. The elders' body mass index (BMI) was calculated according to the Bassey's equation [12], and their daily kilocalories intake was measured by analysis of their nutritional status using 72-hour recall checklist. Leiden-Padua (LIEPAD) questionnaire which was utilized to assess QOL of elders in this study was used first in Italy (Padua and Brescia) and the Netherlands (Leiden). The questionnaire includes two parts [13]. The first and the main part of LIEPAD questionnaire is core component of QOL (CCQOL) and the second part is moderators of QOL (MQOL). The core component of QOL consists of 31 questions divided into seven dimensions as follow: Physical function (5 questions), self-care (6 questions), depression and anxiety (4 questions), cognitive function (5 questions), social performance (3 questions), sexual function (2 questions), and life satisfaction (6 questions). Each question of CCQOL is scored on a four-point Likert scale from zero to three; yields the maximum score of 93 . The MQOL part of the LEIPAD questionnaire consists of 18 questions divided into five dimensions: perceived personality (6 questions), anger (4 questions), social desirability (3 questions), trust in God (2 items), and self-esteem (3 items). Questions are scored by four-point Likert scale $(0-3)$ and 2-point scale $(0-1)$ with the maximum score of 34. In this study we used the Persian version of LEIPAD questionnaire to assess QOL of participants [14]. Validity of the questionnaire was approved by experts' opinion and its reliability (Cronbach's alpha $=94 \%$ ) was approved based on other studies $[15,16]$. The reliability of each of the seven components of CCQOL was also assessed by us in this study using Cronbach's alpha formula as follow: Physical function (87\%), cognitive function (85\%), social performance (84\%), self-care (83\%), sexual function (83\%), life satisfaction ( $82 \%)$ and depression and anxiety $(81 \%)$. For CCQOL, the overall Cronbach's alpha value was 0.83 . We also measured the reliability of each of the five items of MQOL as follow: social desirability (89\%), perceived personality $(85 \%)$, self-esteem $(84 \%)$, anger $(81 \%)$, and trust in 
god (79\%). The overall Cronbach's alpha value for MQOL was 0.84 . Total score of QOL was calculated by summation of scores of CCQOL and MQOL. In this scale, scores below 50, between 50 and 98, and above 98 were classified as low, moderate, and high level of QOL, respectively.

\section{Statistical analysis}

Data was entered into the IBM SPSS statistics software package version 25 and the accuracy of data entry was checked by randomly selecting the data from the software and matching them with the related questionnaires. Spearman test was used to evaluate the correlations between the total score of QOL and each item of CCQOL and MQOL, between the total score of CCQOL and its components, and between total score of MQOL and its items. Homogeneity and equality of variances were checked by Levene's test. Univariable analysis was done using independent $t$-test to determine the factors that were associated with QOL, CCQOL and MQOL. For multivariable analysis, factors with a $p \leq 0.2$ on univariable analysis were fitted into the linear regression model (forward type). In this study, $p$-values less than 0.05 were considered as the significant difference.

\section{Ethical statement}

This study was conducted according to the guidelines laid down in the Declaration of Helsinki. Voluntary participation in this study, using anonymous questionnaire, possibility of access to executives of this study via two exclusive phone lines and keeping confidentiality in all aspects of research were some of the ethical aspects that were applied. Further, the research protocol, as described above, was approved by SUMS ethics board committee by No: IR.SUMS.REC.1395.S254.

\section{Results}

\section{Participants and their characteristics}

Twenty-two out of 408 elders were excluded due to Alzheimer's disease and 386 (94.6\%) were entered to the study. The mean age of participants was $68.12 \pm 6.24$ years. They consisted of $248(64.2 \%)$ participants aged 60 - 69 years, 200 (51.8\%) females, 272 (70.5\%) married, and 350 (90.6\%) who educated up to 12 years. The mean number of persons living with elders was $3 \pm 1.5$ (median $=3$ ). The socioeconomic, demographic, anthropometric and medical backgrounds of interviewees are shown in the Table 1.

\section{Total score of QOL, CCQOL, and MQOL}

The mean total score of QOL was $83.67 \pm 13.75$ (out of 127); representing a moderate level of QOL among the elders. Accordingly, 12 (0.5\%) participants had low QOL, while 281 (72.8\%) and 84 (21.9\%) had moderate and high levels of QOL, respectively. For 9 elders, QOL could not be categorized due to incomplete answers. Total score of CCQOL was $70.68 \pm 9.42$ (out of 93), with an interquartile range (IQR) from 66 - 77. Total score of MQOL was $20.94 \pm 2.30$ (out of 34) with an IQR from $19-22$. 


\section{Correlates of QOL}

Univariable analysis showed that being female, single life, level of education up to 12 years or being jobless (elders and their spouses) and not being the source of family income had a negative statistical association with the total score of QOL (Table 2). Moreover, the history of chronic diseases (vascular, skeletal, and neurological diseases, sleep-related disorders, and hyperlipidemia), chronic pain, facing to violence and not taking medical supplements found to have an inverse correlation with the total score of QOL ( $p<0.2$; Table 2). Other socioeconomic, demographic, anthropometric and medical characteristics of the elders were not correlated with the total score of QOL $(p>0.2)$. Multivariable analysis showed that sleep disorder $(B=-0.15)$, osteoporosis $(B=-0.14)$, female gender $(B=-0.13)$, and not being the source of family income $(B=-0.13)$ had a significant and inverse association with the total score of QOL $(p<0.05)$ (Table 3).

\section{Correlates of CCQOL}

Figure 1 demonstrates the association of the total score of CCQOL with each of its seven components. Physical functioning had the most correlation (0.81) and sexual functioning (0.17) had the least correlation with the total score of CCQOL.

Univariable analysis showed that female gender, single life, being jobless of the elders, and not being the source of family income had a negative association with the total score of CCQOL (Table 2). Further, having history of chronic diseases (cardiovascular, hematological, renal, skeletal, neurological, rheumatic, and psychological diseases, sleep disorders, and hyperlipidemia), chronic pain , facing to violence and taking medical supplements found to have an inverse correlation with CCQOL $(p<0.2 ;$ Table 2$)$. Other socioeconomic, demographic, anthropometric and medical characteristics of the elders were not correlated with QOL score $(p>0.2)$. Multivariable analysis showed that sleep disorder $(B=-0.21)$, facing to violence $(B=-0.21)$, female gender $(B=-0.17)$, migraine $(B=-0.14)$, psychological disease $(B=-0.13)$, and not being the source of family income $(B=-0.09)$ had a significant and inverse correlation with CCQOL $(p<0.05$; Table 3).

\section{CCQOL components}

\section{Physical functioning}

The mean score of physical function was $11.3 \pm 2.6$ (out of 15 ). Sleep disorder $(B=-0.20)$, chronic pain ( $B$ $=-0.18)$, being female $(B=-0.16)$, osteoporosis $(B=-0.12)$, low age of marriage $(B=-0.12)$, and migraine $(B=-0.11)$ had a negative and significant association with physical function of the older adults.

\section{Cognitive functioning}

The mean score of cognitive function was $12.1 \pm 2.5$ (out of 15$)$. Sleep disorder $(B=-0.20)$, migraine $(B=$ $-0.17)$, and facing to violence $(B=-0.14)$ had a significant association with decrease of cognitive functioning. 
The mean score of depression and anxiety was $9.4 \pm 2.9$ (out of 12 ). Migraine $(B=0.19)$, psychological disease $(B=0.17)$, being female $(B=0.16)$, sleep disorder $(B=0.14)$, and facing to violence $(B=0.11)$ had a significant and positive association with depression and anxiety scale in the elders.

\section{Self-care}

The mean score of self-care was $16.6 \pm 2.3$ (out of 18$)$. Female gender $(B=-0.19)$, older age $(B=-0.19)$, osteoporosis $(B=-0.15)$, facing to violence $(B=-0.10)$, and hypertension $(B=-0.10)$ significantly decreased the self-care of the elders.

\section{Social Functioning}

The mean score of social function was $6.6 \pm 2.0$ (out of 9$)$. Facing to violence $(B=-0.25)$, single life $(B=$ $-0.19)$, female gender $(B=-0.13)$, and not being the source of family income $(B=-0.13)$ had a significant and opposite association with social functioning of the elders.

\section{Life satisfaction}

The mean score of life satisfaction was $10.30 \pm 2.36$ (out of 18). Facing to violence $(B=-0.18)$, sexual problem $(B=-0.15)$, sleep disorder $(B=-0.12)$, and not being the source of family income $(B=-0.15)$ decreased the life satisfaction among the elders.

\section{Sexual functioning}

The mean score of sexual function was $4.1 \pm 1.6$ (out of 6$)$. Single life $(B=-0.66)$, female gender $(B=$ $-0.18)$, sexual problem $(B=-0.16)$ and older age $(B=-0.14)$ had a significant and inverse association with the sexual functioning of the elders.

\section{MQOL Components and its Correlates}

The mean score of perceived personality was $4.02 \pm 1.22$ (out of 8 ) and the mean score of anger was $9.20 \pm 1.06$ (out of 12). Moreover, social desirability had a mean score of $0.28 \pm 0.55$ (out of 3 ), compared to self-esteem that had mean of $6.42 \pm 0.79$ (out of 9), and trust in God with the mean of $1.0 \pm 0.07$ (out of 2). Among the five items of MQOL; perceived personality (0.78) and trust in God (0.1) had the most and the least correlation with total score of MQOL, respectively (Figure 2). Univariable analysis showed that female gender, not having supplementary insurance, not being the source of family income and sleep disorder had an inverse and significant association with MQOL (Table 2). Moreover, having history of chronic diseases (liver disease, psychological disease, osteoporosis, skin disease, migraine, hematological disease, inability to walking, and sexual problem), chronic pain and facing to violence found to have an inverse correlation with MQOL $(p<0.2$; Table 2). Multivariable analysis showed that, sexual problem $(B=-0.17)$, facing to violence $(B=-0.16)$, not having supplementary insurance $(B=-0.15)$, 
inability to walking $(B=-0.14)$, and migraine $(B=-0.12)$ had an inverse association with MQOL $(p<0.05$; Table 3).

\section{Discussion}

The results of this study revealed that at least seven out of ten elders in the study region had a moderate level of QOL. Also, the elder women, the elders with chronic diseases (sleep disturbance, osteoporosis) or those who were not the source of their family income had a lower level of QOL. Moreover, facing to violence was inversely associated with both CCQOL and MQOL in the elders and sexual problems and not having the supplementary insurance decreased the elders' MQOL. Among chronic diseases; sleep disturbance had the most inverse association with QOL and CCQOL, while sexual problems had the most association with MQOL. Furthermore, physical functioning and perceived personality had the most correlation with CCQOL and MQOL, respectively.

Population aging is one of the most challengeable public health issues in the today's world $[3,17]$. As a result, prevalence of chronic diseases and need to care of older adults has been increased [18]. On the other hand, to achieve a higher level of QOL in the elders has been more concerned by policy makers compared to solely rising their life expectancy [19]. However, developing countries, unlike developed countries, are not prepared enough to manage the health, social and economic consequences of aging [20].

Zeitlhofer et al. in Austria revealed that a substantial association was found between sleep quality and total score of QOL. They suggested that poor sleep quality could be used as a screening method in exploration of patient's QOL [21] , which is in line with our study. Association of quality of sleep with QOL was also found in another study [22].

Similar to our results, Lips and van Schoor [23] and Madureira et al. [24] found that osteoporosis was associated with deterioration of QOL in the elders. Lee et al. revealed that gender was not correlated with QOL [25], which is in contrast to our results , as well as the results from the study by Lemos et al., in which they concluded that QOL was lower in the elderly women than elderly men [26]. Despite some other studies [27-29], we did not find any association between the low level of income and QOL, although a positive association was found between being the source of family income and QOL; a new finding that was not assessed in other studies. We also showed that birthplace (urban versus rural) of the elders and their spouse did not have any association with their QOL. This finding is inconsistent with the results from another study conducted in Spain [30].

In the recent years, scientists have been more concerned about different aspects of sexuality as the determinants of QOL in the elders. Flynn and Gow concluded that sexual function is a significant predictor of QOL in the older adults [31]. We showed that sexual function, was positively associated with MQOL in the elders. In addition, the incidence of depression has increased in many countries, as well as in the Middle East in the past two decades [32]. Similar to our study, Canuto et al. found that the incidence of depression and anxiety disorders had negative relationship with QOL in the elders, especially 
in women [33]. In another study, violence toward elders was associated with diminishing of QOL in them, as we concluded in this study [34]. Brovold et al. showed that physical function had a significant association with aging, which means it is important to encourage elders to being active physically and thereby increasing their QOL [35]. Similarly, we found that physical function was the strongest predictor of CCQOL among its components.

Our study had some limitations and strengths. We could not assess the QOL of those elders who were not under the coverage of health centers. However, this group consisted of only about $5 \%$ of all elders in Shiraz city. Moreover, there are limited nursing homes this city. Another point is that, to detect a cause and effect between QOL and other factors, it is needed to conduct a kind of longitudinal study. On the other hand, and as strength points, this study is among scarce studies that assessed MQOL and its association with QOL in the elders. In addition, we measured the correlation between different socioeconomic, demographic, anthropometric, and medical backgrounds with QOL, CCQOL and MQOL. Also, the correlations between the components of $\mathrm{CCQOL}$ and $\mathrm{MQOL}$ with their related scores were investigated.

\section{Conclusions}

Four out of five elders in the Shiraz region have a moderate level of QOL, while the elder females and the elders with chronic diseases (especially those with sleep disturbance or osteoporosis), as well as the elders who are not the source of their family income have a lower level of QOL. Facing to violence also has an association with lower scales of both CCQOL and MQOL, while sexual problems and not having the supplementary insurance, decrease MQOL. Therefore, QOL in the elders can be improved through an integrated care program in the health centers for changing the above conditions, especially in the women, while the role of elders' families in this regard could not be overlooked.

\section{Abbreviations}

QOL: Quality of life; WHO: World Health Organization; LIEPAD: Leiden-Padua Questionnaire; IQR: Interquartile Range; CCQOL: Core Components of Quality of Life; MQOL: Moderators of Quality of Life

\section{Declarations}

\section{Ethics approval and consent to participate}

This study was approved by Shiraz University of Medical Sciences ethics board committee by No: IR.SUMS.REC. 1395.S254.

\section{Consent for publication}

Not applicable

\section{Availability of data and materials}


The datasets used and/or analyzed during the current study are available from the corresponding author on reasonable request.

\section{Competing interests}

The authors declare that they have no competing interests

\section{Funding}

There was no funding source for this study.

\section{Authors' contributions}

BH: Conceptualization, supervision, writing - review \& editing, PK: writing - original draft, EKH: analysis and interpretation of the data, writing - review \& editing, YM: collected the data, MB: collected the data, writing - review \& editing

\section{Acknowledgements}

The authors would like to thank all the elders and their families who participated in this study and responded honestly to our questions.

\section{References}

1. Gebremariam KM, Sadana R. On the ethics of healthy ageing: setting impermissible trade-offs relating to the health and well-being of older adults on the path to universal health coverage. Int $J$ Equity health. 2019;18(1):1-16. https://doi.org/10.1186/s12939-019-0997-z PubMed PMID: 31488220

2. Kojima G, lliffe S, Jivraj S, Walters K. Association between frailty and quality of life among community-dwelling older people: a systematic review and meta-analysis. J Epidemiol Community Health. 2016;70(7):716-21. https://doi.org/10.1136/jech-2015-206717 PubMed PMID: 26783304

3. Rzymowski W, Surowiec A. Selected econometric methods of modelling the world's population. Econometrics. 2018;22(2):34-44.

4. World Health Organization.World report on ageing and health 2015.Available From: https://www.who.int/ageing/events/world-report-2015-launch/en/. Accessed in: 8.3.2020

5. Mehri, N., Messkoub, M. \& Kunkel, S. Trends, Determinants and the Implications of Population Aging in Iran. Ageing Int (2020). Available From:https://doi.org/10.1007/s12126-020-09364-z. Accessed in: 8.3.2020

6. Elkjær M, Primdahl J, Mogensen CB, Brabrand M, Gram B, editors. Quality of life among acutely admitted elderly with and without healthcare-A cross sectional study. The Eur Emerge Med Congress; 2019. Prague, Czech Republic. 
7. Hinek S, Stanić I, Škarica J. Importance of promoting quality of life of elderly people under the influence of globalization. Ekonomski Vjesnik. 2019;32(1):9-21.

8. Lee H-J, Song J-H. The Factors Affecting the Quality of Life for Korean Elders Placed under LongTerm Care Facilities in South Korea and the United States. International Information Institute (Tokyo) Information. 2017;20(3B):2239-47.

9. Utian WH, Janata JW, Kingsberg SA, Schluchter M, Hamilton JC. The Utian Quality of Life (UQOL) Scale: development and validation of an instrument to quantify quality of life through and beyond menopause. Menopause. 2018;25(11):1224-31. https://doi.org/10.1097/GME.0000000000001223 PubMed PMID: 30358717

10. Mellencamp KA. Depressive Symptoms Trajectories Following Child Death in Later Life: Variation by Race-Ethnicity: Bowling Green State University; 2019.Available From: http://rave.ohiolink.edu/etdc/view?acc_num=bgsu1563465712524515. Accessed in: 8.3.2020

11. Khooshemehri G, Kaviani M, Asmari M, Rajabian H, Naserkhaki V. Comparison of quality of life for elderly men and women elderly nursing home resident by Alborz province in 1390 . Alborz University Medical Journal. 2013;2(1):19-24.[In Persian]

12. Lehmann A, Bassey E, Morgan $K$, Dallosso H. Normal values for weight, skeletal size and body mass indices in 890 men and women aged over 65 years. Clin Nutr. 1991;10(1):18-22. https://doi.org/10.1016/0261-5614(91)90076-o PubMed PMID: 16839889

13. Cheraghi P, Cheraghi Z, Doosti-Irani A, Nedjat S, Nedjat S. Quality of life in elderly Iranian population using leiden-padua questionnaire: A systematic review and meta-analysis. Int J Prev Med 2017;8 (1): 55. https://doi.org/10.4103/ijpvm.IJPVM_265_16 PubMed PMID: 28928913

14. De Leo D, Diekstra RF, Lonnqvist J, Lonnqvist J, Cleiren MH, Frisoni GB, et al. LEIPAD, an internationally applicable instrument to assess quality of life in the elderly. Behav Med. 1998;24(1):17-27. https://doi.org/10.1080/08964289809596377 PubMed PMID: 9575388

15. Hesamzadeh A, Maddah SB, Mohammadi F, Fallahi Khoshknab M, Rahgozar M. Comparison of elderlys" quality of life" living at homes and in private or public nursing homes. Iran J Ageing. 2010;4(4):66-74.[In Persian]

16. Javanvash Z, Mojdekanlu M, Rastaqhi S, Rad M. The effect of model-based self-management program $5 \mathrm{~A}$ on quality of life of elderly patients with acute coronary syndrome. Journal of Sabzevar University Of Medical Sciences. 2018, 25( 1):75- 82. [In Persian]

17. Reitan I, Dahlin LB, Rosberg H-E. Patient-reported quality of life and hand disability in elderly patients after a traumatic hand injury-a retrospective study. Health Qual Life Outcomes. 2019;17(1):148. https://doi.org/10.1186/s12955-019-1215-9 PubMed PMID: 31470865

18. Rizzuto D, Melis RJ, Angleman S, Qiu C, Marengoni A. Effect of chronic diseases and multimorbidity on survival and functioning in elderly adults. J Am Geriatr Soc. 2017;65(5):1056-60. https://doi.org/10.1111/jgs.14868 PubMed PMID: 28306158

19. Lok N, Lok S, Canbaz M. The effect of physical activity on depressive symptoms and quality of life among elderly nursing home residents: Randomized controlled trial. Arch Gerontol Geriatr. 
2017;70:92-8. https://doi.org/10.1016/j.archger.2017.01.008 PubMed PMID: 28110207

20. Farajzadeh M, Gheshlagh RG, Sayehmiri K. Health related quality of life in Iranian elderly citizens: a systematic review and meta-analysis. Int J Community Based Nurs Midwifery. 2017;5(2):100.

PubMed PMID: 28409164

21. Zeitlhofer J, Schmeiser Rieder A, Tribl G, Rosenberger A, Bolitschek J, Kapfhammer G, et al. Sleep and quality of life in the Austrian population. Acta Neurol Scand. 2000;102(4):249-57. https://doi.org/10.1034/j.1600-0404.2000.102004249.x PubMed PMID: 11071111

22. 2 Honarvar B, Bagheri Lankarani K, Azadegan M, Khaksar E, Jafari F, Rahmani Fard T. The Prevalence and predictors of sleep disturbance in the elderly: A population-based study in Shiraz, Iran, Shiraz E-Med J. Online ahead of Print ; 20(11):e88349. doi: 10.5812/semj.88349.

23. Lips P, van Schoor NM. Quality of life in patients with osteoporosis. Osteoporos Int. 2005;16(5):44755.

24. Madureira MM, Bonfá E, Takayama L, Pereira RM. A 12-month randomized controlled trial of balance training in elderly women with osteoporosis: improvement of quality of life. Maturitas. 2010;66(2):206-11. https://doi.org/10.1016/j.maturitas.2010.03.009 PubMed PMID: 20395080

25. Lee Y, Shinkai S. A comparison of correlates of self-rated health and functional disability of older persons in the Far East: Japan and Korea. Arch Gerontol Geriatr. 2003;37(1):63-76. https://doi.org/10.1016/s0167-4943(03)00021-9 PubMed PMID: 12849074

26. Lemos CF, Rodrigues MP, Veiga JRP. Family income is associated with quality of life in patients with chronic kidney disease in the pre-dialysis phase: a cross sectional study. Health Qual Life Outcomes. 2015;13(1):202. https://doi.org/10.1186/s12955-015-0390-6 PubMed PMID: 26690667

27. Zhang $S$, Xiang W. Income gradient in health-related quality of life-the role of social networking time. Int J Equity Health. 2019;18(1):44. https://doi.org/10.1186/s12939-019-0942-1 PubMed PMID: 30876427

28. Lam CLK, Guo VY, Wong CKH, Yu EYT, Fung CSC. Poverty and health-related quality of life of people living in Hong Kong: comparison of individuals from low-income families and the general population. J Public Health. 2017;39(2):258-65. https://doi.org/10.1093/pubmed/fdw046 PubMed PMID: 27222238

29. Rebelo MAB, Cardoso EM, Robinson PG, Vettore MV. Demographics, social position, dental status and oral health-related quality of life in community-dwelling older adults. Qual Life Res. 2016;25(7):1735-42. https://doi.org/10.1007/s11136-015-1209-y PubMed PMID: 26708574

30. Balboa-Castillo T, León-Muñoz LM, Graciani A, Rodríguez-Artalejo F, Guallar-Castillón P. Longitudinal association of physical activity and sedentary behavior during leisure time with health-related quality of life in community-dwelling older adults. Health Qual Life Outcomes. 2011;9(1):47. https://doi.org/10.1186/1477-7525-9-47 PubMed PMID: 21708011

31. Flynn T-J, Gow AJ. Examining associations between sexual behaviours and quality of life in older adults. Age Ageing. 2015;44(5):823-8. https://doi.org/10.1093/ageing/afv083 PubMed PMID: 26178206 
32. Hamidizadeh N, Ranjbar S, Ghanizadeh A, Parvizi MM, Jafari P, Handjani F. Evaluating prevalence of depression, anxiety and hopelessness in patients with Vitiligo on an Iranian population. Health Qual Life Outcomes. 2020;18(1):20. https://doi.org/10.1186/s12955-020-1278-7 PubMed PMID: 32013982

33. Canuto A, Weber K, Baertschi M, Andreas S, Volkert J, Dehoust MC, et al. Anxiety disorders in old age: psychiatric comorbidities, quality of life, and prevalence according to age, gender, and country. Am J Geriatr Psychiatry. 2018;26(2):174-85. https://doi.org/10.1016/j.jagp.2017.08.015 PubMed PMID: 29031568

34. Honarvar B, Bahadori F, Khaksar E, Gheibi Z, Asadollahi A, Rabiey Faradonbeh M. The Impact of Abuse on the Quality of Life of the Elderly: A Population-based Survey in Iran. Korean J Prev Med. 2019;0(0). doi: 10.3961/jpmph.19.210

35. Brovold T, Skelton DA, Sylliaas H, Mowe M, Bergland A. Association between health-related quality of life, physical fitness, and physical activity in older adults recently discharged from hospital. J Aaging Phys Act. 2014;22(3):405-13. https://doi.org/10.1123/japa.2012-0315 PubMed PMID: 23981441

\section{Tables}

Table 1. Socioeconomic, demographic, anthropometric and medical characteristics of elders $(n=386)$ 


\begin{tabular}{|c|c|c|c|c|c|}
\hline Characteristic & $n(\%)$ & Characteristic & $n(\%)$ & Characteristic & $n(\%)$ \\
\hline Age (year) & & Supplementary Insurance & & Chronic Pain & \\
\hline $60-69$ & $\begin{array}{l}248 \\
(64.2)\end{array}$ & Yes & $281(72.7)$ & Yes & $\begin{array}{l}259 \\
(67)\end{array}$ \\
\hline $70-79$ & $\begin{array}{l}114 \\
(29.5) \\
\end{array}$ & No & $105(27.2)$ & No & $\begin{array}{l}127 \\
(32.9)\end{array}$ \\
\hline$\geq 80$ & $24(6.2)$ & House Ownership Status & & Renal Disease & \\
\hline Gender & & Landlord & $346(89.6)$ & Yes & $\begin{array}{l}78 \\
(20.2) \\
\end{array}$ \\
\hline Male & $\begin{array}{l}186 \\
(48.1)\end{array}$ & Tenant & $40(10.3)$ & No & $\begin{array}{l}308 \\
(79.7) \\
\end{array}$ \\
\hline Female & $\begin{array}{l}200 \\
(51.8)\end{array}$ & $\begin{array}{l}\text { Being the Main Decision Maker about Family } \\
\text { Finances }\end{array}$ & & Osteoporosis & \\
\hline Level of Education & & Yes & $254(65.8)$ & Yes & $\begin{array}{l}175 \\
(45.3) \\
\end{array}$ \\
\hline$\leq 12$ (year) & $\begin{array}{l}350 \\
(90.6)\end{array}$ & No & $132(34.1)$ & No & $\begin{array}{l}211 \\
(54.6)\end{array}$ \\
\hline$>12$ & $36(9.3)$ & Occupation & & Hematological Disease & \\
\hline $\begin{array}{l}\text { Level of Education of } \\
\text { Spouse }\end{array}$ & & Yes & $43(11.1)$ & Yes & $\begin{array}{l}65 \\
(16.8)\end{array}$ \\
\hline$\leq 12$ (year) & $\begin{array}{l}356 \\
(92.2)\end{array}$ & No & $343(88.8)$ & No & $\begin{array}{l}321 \\
(83.1)\end{array}$ \\
\hline$>12$ & $27(6.9)$ & Tobacco Smoking & & Auditory Impairment & \\
\hline Marital Status & & Yes & $44(11.3)$ & Yes & $\begin{array}{l}378 \\
(97.9) \\
\end{array}$ \\
\hline Married & $\begin{array}{l}272 \\
(70.4)\end{array}$ & No & $342(88.6)$ & No & $8(2)$ \\
\hline Single life & $\begin{array}{l}114 \\
(29.5)\end{array}$ & Daily Calories Intake (kcal) & & Diabetes Mellitus & \\
\hline Birth Place & & $<1600$ & $266(68.9)$ & Yes & $\begin{array}{l}119 \\
(30.8)\end{array}$ \\
\hline Village & $33(8.5)$ & $\geq 1600$ & $117(30.3)$ & No & $\begin{array}{l}267 \\
(69.1) \\
\end{array}$ \\
\hline City & $\begin{array}{l}353 \\
(91.4) \\
\end{array}$ & Cardiac Disease & & Hyperlipidemia & \\
\hline Relativity with Spouse & & Yes & $66(17)$ & Yes & $\begin{array}{l}184 \\
(47.6) \\
\end{array}$ \\
\hline 1st degree & $\begin{array}{l}90 \\
(23.3)\end{array}$ & No & $320(82.9)$ & No & $\begin{array}{l}202 \\
(52.3)\end{array}$ \\
\hline Non 1st degree & $\begin{array}{l}294 \\
(76.1)\end{array}$ & Hypertension & & Sexual Problem & \\
\hline Age at the First Marriage & & Yes & $216(56)$ & Yes & $58(15)$ \\
\hline$<18$ & $\begin{array}{l}161 \\
(41.7) \\
\end{array}$ & No & $170(44)$ & No & $\begin{array}{l}328 \\
(84.9)\end{array}$ \\
\hline $18-24$ & $\begin{array}{l}113 \\
(29.2)\end{array}$ & BMI $\mathrm{Kg} / \mathrm{m}^{2}$ (Bassey Method) & & Inability to Walk & \\
\hline$\geq 25$ & $\begin{array}{l}110 \\
(28.4)\end{array}$ & Mean \pm SD (Median) & $\begin{array}{l}25.8 \pm 5.0 \\
(25.6)\end{array}$ & Yes & $\begin{array}{l}46 \\
(11.9) \\
\end{array}$ \\
\hline Income to Cost ratio & & Migraine & & No & $\begin{array}{l}340 \\
(88)\end{array}$ \\
\hline$\leq 1$ & $\begin{array}{l}206 \\
(53.3) \\
\end{array}$ & Yes & $77(19.9)$ & $\begin{array}{l}\text { Taking Medical } \\
\text { Supplement }\end{array}$ & \\
\hline$>1$ & $\begin{array}{l}84 \\
(21.7)\end{array}$ & No & $309(80.1)$ & Yes & $\begin{array}{l}346 \\
(89.6) \\
\end{array}$ \\
\hline $\begin{array}{l}\text { Being the Source of Family } \\
\text { Income }\end{array}$ & & Psychological Disease & & No & $\begin{array}{l}40 \\
(10.3)\end{array}$ \\
\hline
\end{tabular}




\begin{tabular}{|l|l|l|l|l|l|} 
Yes & $\begin{array}{l}222 \\
(57.5)\end{array}$ & Yes & $84(21.7)$ & & \\
\hline No & $\begin{array}{l}159 \\
(41.1)\end{array}$ & No & $302(78.2)$ & & \\
\hline
\end{tabular}

Table 2. Univariable analysis of association between studied characteristics and quality of life and its components in the elders

${ }^{1}$ CCQOL: Core Components of Quality of Life, ${ }^{2}$ MQOL: Moderators of Quality of Life, ${ }^{3}$ QOL: Quality of Life

Table 3. Multivariable analysis showing statistically significant correlates of QOL,CCQOL and MQOL in the elders

${ }^{1} \boldsymbol{P}$ : $p$ value, ${ }^{2} \mathrm{CI}$ : Confidence Interval, ${ }^{3} \mathrm{QOL}$ : Quality of Life, ${ }^{4} \mathrm{CCQOL}$ : Core Components of Quality of Life, ${ }^{5} \mathrm{MQOL}$ : Moderators of Quality of Life

\section{Figures}




\begin{tabular}{|c|c|c|c|c|c|c|c|}
\hline Characteristic & $\mathrm{CCQOL}^{1}$ & $\mathrm{MQOL}^{2}$ & $\mathrm{QOL}^{3}$ & Characteristic & CCQOL & MQOL & QOL \\
\hline Gender & & & & Sexual Problem & & & \\
\hline Male & $72.5 \pm 8.1$ & $\begin{array}{c}21.2 \pm \\
2.1 \\
\end{array}$ & $93.7 \pm 8.2$ & Yes & $69.0 \pm 9.5$ & $\begin{array}{l}20.8 \pm \\
2.0\end{array}$ & $89.8 \pm 9.9$ \\
\hline Female & $68.9 \pm 10.1$ & $\begin{array}{c}20.6 \pm \\
2.4 \\
\end{array}$ & $\begin{array}{c}89.5 \pm \\
10.6 \\
\end{array}$ & No & $70.9 \pm 9.3$ & $21.9 \pm 2.3$ & $91.9 \pm 9.7$ \\
\hline$p$ value & $<0.01$ & 0.031 & $<0.001$ & $p$ value & 0.276 & 0.001 & 0.149 \\
\hline Marital status & & & & Migraine & & & \\
\hline Single/Single Life & $\begin{array}{l}69.5 \pm \\
10.4\end{array}$ & $\begin{array}{c}20.7 \pm \\
2.3 \\
\end{array}$ & $\begin{array}{c}90.1 \pm \\
11.1 \\
\end{array}$ & Yes & $\begin{array}{c}67.0 \pm \\
11.6 \\
\end{array}$ & $20.0 \pm 2.2$ & $\begin{array}{c}88.0 \pm \\
12.4 \\
\end{array}$ \\
\hline Married & $71.1 \pm 8.9$ & $\begin{array}{c}21.0 \pm \\
2.2 \\
\end{array}$ & $92.1 \pm 9.1$ & No & $71.6 \pm 8.5$ & $21.9 \pm 2.4$ & $92.4 \pm 8.8$ \\
\hline$p$ value & 0.120 & 0.372 & 0.060 & $p$ value & 0.002 & 0.008 & $<0.001$ \\
\hline Education (year) & & & & Hyperlipidemia & & & \\
\hline$<=12$ & $70.5 \pm 9.5$ & $\begin{array}{c}20.8 \pm \\
2.2\end{array}$ & $86.2 \pm 9.9$ & Yes & $69.1 \pm 9.9$ & $20.8 \pm 2.3$ & $\begin{array}{c}89.8 \pm \\
10.3 \\
\end{array}$ \\
\hline$>12$ & $72.3 \pm 8.3$ & $\begin{array}{c}21.4 \pm \\
2.5 \\
\end{array}$ & $91.3 \pm 9.8$ & No & $72.1 \pm 8.7$ & $21.0 \pm 2.2$ & $93.1 \pm 9.0$ \\
\hline$p$ value & 0.244 & 0.698 & 0.021 & $p$ value & 0.002 & 0.578 & 0.035 \\
\hline Education of spouse (year) & & & & Rheumatic Disease & & & \\
\hline$\leq 12$ & $70.5 \pm 9.5$ & $\begin{array}{c}20.9 \pm \\
2.3 \\
\end{array}$ & $91.4 \pm 9.8$ & Yes & $\begin{array}{c}66.2 \pm \\
11.7 \\
\end{array}$ & $20.8 \pm 0.9$ & $\begin{array}{c}86.0 \pm \\
11.6 \\
\end{array}$ \\
\hline$>12$ & $72.3 \pm 8.1$ & $\begin{array}{c}21.2 \pm \\
2.3 \\
\end{array}$ & $93.6 \pm 9.3$ & No & $70.8 \pm 9.3$ & $20.9 \pm 2.3$ & $91.7 \pm 9.7$ \\
\hline$p$ value & 0.286 & 0.902 & 0.024 & $p$ value & 0.116 & 0.949 & 0.116 \\
\hline Having Job & & & & Severe Weight Loss & & & \\
\hline Yes & $72.8 \pm 5.7$ & $\begin{array}{c}20.9 \pm \\
1.5 \\
\end{array}$ & $93.7 \pm 6.2$ & Yes & $\begin{array}{c}67.8 \pm \\
10.5 \\
\end{array}$ & $20.6 \pm 2.2$ & $\begin{array}{c}88.5 \pm \\
10.9 \\
\end{array}$ \\
\hline No & $70.4 \pm 9.7$ & $\begin{array}{c}20.9 \pm \\
2.3 \\
\end{array}$ & $\begin{array}{c}91.3 \pm \\
10.1 \\
\end{array}$ & No & $70.8 \pm 9.3$ & $20.9 \pm 2.3$ & $91.8 \pm 9.6$ \\
\hline$p$ value & 0.022 & 0.951 & 0.011 & $p$ value & 0.117 & 0.428 & 0.117 \\
\hline Spouse having job & & & & Facing Violence & & & \\
\hline Yes & $70.9 \pm 9.0$ & $\begin{array}{c}20.9 \pm \\
2.2 \\
\end{array}$ & $91.8 \pm 9.4$ & Yes & $\begin{array}{c}67.8 \pm \\
10.5 \\
\end{array}$ & $20.6 \pm 2.0$ & $\begin{array}{c}88.4 \pm \\
10.5 \\
\end{array}$ \\
\hline No & $69.3 \pm 11.1$ & $\begin{array}{c}20.8 \pm \\
2.4 \\
\end{array}$ & $\begin{array}{c}90.0 \pm \\
11.6 \\
\end{array}$ & No & $72.7 \pm 7.8$ & $21.1 \pm 2.4$ & $93.9 \pm 8.5$ \\
\hline$p$ value & 0.269 & 0.501 & 0.131 & $p$ value & $<0.001$ & $<0.001$ & $<0.001$ \\
\hline $\begin{array}{l}\text { Being the Source of Family } \\
\text { Income }\end{array}$ & & & & $\begin{array}{l}\text { Hematological } \\
\text { Disease }\end{array}$ & & & \\
\hline Yes & $72.2 \pm 8.5$ & $\begin{array}{c}20.9 \pm \\
2.2 \\
\end{array}$ & $\begin{array}{l}93.2 \pm \\
8.9 \\
\end{array}$ & Yes & $68.5 \pm 8.2$ & $20.3 \pm 1.8$ & $\begin{array}{c}89.1 \pm \\
10.3 \\
\end{array}$ \\
\hline No & $\begin{array}{l}68.6 \pm \\
10.0\end{array}$ & $\begin{array}{c}20.8 \pm \\
2.3 \\
\end{array}$ & $\begin{array}{c}89.4 \pm \\
10.4 \\
\end{array}$ & No & $71.1 \pm 9.6$ & $21.0 \pm 2.3$ & $92.4 \pm 9.4$ \\
\hline$p$ value & $<0.001$ & 0.023 & $<0.001$ & $p$ value & 0.003 & 0.108 & 0.353 \\
\hline Supplementary Insurance & & & & Hepatic Disease & & & \\
\hline Yes & $70.9 \pm 9.6$ & $\begin{array}{c}23.9 \pm \\
2.3 \\
\end{array}$ & $91.9 \pm 9.8$ & Yes & $\begin{array}{c}69.2 \pm \\
11.9 \\
\end{array}$ & $20.8 \pm 2.2$ & $\begin{array}{c}90.0 \pm \\
12.2\end{array}$ \\
\hline No & $69.8 \pm 8.7$ & $\begin{array}{c}20.9 \pm \\
2.3 \\
\end{array}$ & $90.6 \pm 9.5$ & No & $70.8 \pm 9.0$ & $21.9 \pm 2.3$ & $91.7 \pm 9.4$ \\
\hline$p$ value & 0.206 & 0.003 & 0.312 & $p$ value & 0.603 & 0.036 & 0.312 \\
\hline Inability to walk & & & & Osteoporosis & & & \\
\hline Yes & $65.5 \pm 12.8$ & $\begin{array}{c}20.1 \pm \\
2.3 \\
\end{array}$ & $\begin{array}{c}86.6 \pm \\
13.1 \\
\end{array}$ & Yes & $\begin{array}{c}68.4 \pm \\
10.3 \\
\end{array}$ & $20.5 \pm 2.2$ & $\begin{array}{c}88.9 \pm \\
10.6 \\
\end{array}$ \\
\hline No & $71.3 \pm 8.6$ & $\begin{array}{c}21.1 \pm \\
2.2 \\
\end{array}$ & $92.2 \pm 9.0$ & No & $72.4 \pm 8.1$ & $22.2 \pm 2.3$ & $\begin{array}{l}93.6 \pm \\
8.4 \\
\end{array}$ \\
\hline$p$ value & 0.004 & 0.020 & 0.015 & $p$ value & $<0.001$ & 0.103 & $<0.001$ \\
\hline Sleep Disorder & & & & Cardiac Disease & & & \\
\hline Yes & $68.2 \pm 9.4$ & $20.1 \pm$ & $88.9 \pm 9.5$ & Yes & $81.3 \pm$ & $20.1 \pm 1.7$ & $87.5 \pm 7.3$ \\
\hline
\end{tabular}




\begin{tabular}{|c|c|c|c|c|c|c|c|}
\hline & & 2.2 & & & 13.9 & & \\
\hline No & $73.6 \pm 8.5$ & $\begin{array}{c}21.2 \pm \\
2.3 \\
\end{array}$ & $94.8 \pm 9.0$ & No & $\begin{array}{c}84.1 \pm \\
13.6 \\
\end{array}$ & $20.9 \pm 2.3$ & $91.7 \pm 9.8$ \\
\hline$p$ value & $<0.001$ & 0.012 & $<0.001$ & $p$ value & 0.126 & 0.705 & 0.215 \\
\hline Chronic Pain & & & & Hypertension & & & \\
\hline Yes & $69.3 \pm 9.6$ & $\begin{array}{c}20.7 \pm \\
2.3 \\
\end{array}$ & $\begin{array}{c}90.0 \pm \\
10.0 \\
\end{array}$ & Yes & $\begin{array}{c}69.5 \pm \\
10.0 \\
\end{array}$ & $20.9 \pm 2.3$ & $\begin{array}{c}90.3 \pm \\
10.6 \\
\end{array}$ \\
\hline No & $73.3 \pm 8.4$ & $\begin{array}{c}21.3 \pm \\
2.1 \\
\end{array}$ & $94.6 \pm 8.6$ & No & $72.1 \pm 8.3$ & $20.9 \pm 2.2$ & $93.2 \pm 8.3$ \\
\hline$p$ value & $<0.001$ & 0.024 & 0.011 & $p$ value & 0.005 & 0.984 & 0.102 \\
\hline Taking Medical Supplement & & & & $\begin{array}{l}\text { Psychological } \\
\text { Disease }\end{array}$ & & & \\
\hline Yes & $74.5 \pm 6.2$ & $\begin{array}{c}21.0 \pm \\
2.4 \\
\end{array}$ & $95.5 \pm 7.4$ & Yes & $\begin{array}{c}80.8 \pm \\
10.9 \\
\end{array}$ & $20.5 \pm 2.1$ & $87.5 \pm 9.7$ \\
\hline No & $70.2 \pm 9.6$ & $\begin{array}{c}20.9 \pm \\
2.2 \\
\end{array}$ & $91.1 \pm 9.9$ & No & $\begin{array}{c}84.4 \pm \\
14.3 \\
\end{array}$ & $21.0 \pm 2.3$ & $92.7 \pm 9.5$ \\
\hline$p$ value & $<0.001$ & 0.804 & 0.030 & $p$ value & 0.032 & 0.166 & 0.207 \\
\hline Dermatological Disease & & & & Renal Disease & & & \\
\hline Yes & $67.9 \pm 9.1$ & $\begin{array}{c}20.4 \pm \\
2.2 \\
\end{array}$ & $88.3 \pm 9.7$ & Yes & $\begin{array}{c}69.2 \pm \\
11.9 \\
\end{array}$ & $20.8 \pm 2.4$ & $\begin{array}{c}89.6 \pm \\
10.7 \\
\end{array}$ \\
\hline No & $70.8 \pm 9.4$ & $\begin{array}{c}21.9 \pm \\
2.3 \\
\end{array}$ & $91.8 \pm 9.7$ & No & $70.8 \pm 9.0$ & $20.9 \pm 2.2$ & $92.0 \pm 9.5$ \\
\hline$p$ value & 0.336 & 0.034 & 0.147 & $p$ value & 0.042 & 0.550 & 0.214 \\
\hline
\end{tabular}

\begin{tabular}{|c|c|c|c|c|}
\hline Characteristic & Standardized B & $p^{1}$ & Unstandardized $ß$ & $95 \% \mathrm{CI}^{2}$ \\
\hline \multicolumn{5}{|l|}{$\mathrm{QOL}^{3}$} \\
\hline Sleep disorder & -0.15 & $<0.001$ & -4.09 & $(-5.86,-2.32)$ \\
\hline Osteoporosis & -0.14 & $<0.001$ & -3.25 & $(-7.90,-2.59)$ \\
\hline Gender (Female vs Male) & -0.13 & $<0.001$ & -3.69 & $(-5.47,-1.91)$ \\
\hline Not being the source of family income & -0.13 & 0.042 & -1.86 & $(-3.66,-0.06)$ \\
\hline \multicolumn{5}{|l|}{$\mathrm{CCQOL}^{4}$} \\
\hline Sleep disorder & -0.21 & 0.028 & -4.01 & $(-6.58,-1.43)$ \\
\hline Facing to violence & -0.21 & 0.031 & -2.16 & $(-5.34,-0.25)$ \\
\hline Gender (Female vs Male) & -0.17 & 0.007 & -4.11 & $(-7.10,-1.11)$ \\
\hline Migraine & -0.14 & 0.006 & -5.68 & $(-9.72,-1.63)$ \\
\hline Psychological Disease & -0.13 & 0.012 & -0.95 & $(-2.48,-0.80)$ \\
\hline Not being the source of family income & -0.09 & 0.018 & -2.37 & $(-5.73,-0.53)$ \\
\hline \multicolumn{5}{|l|}{$\mathrm{MQOL}^{5}$} \\
\hline Sexual problem & -0.17 & 0.001 & -1.15 & $(-1.82,-0.48)$ \\
\hline Facing to violence & -0.16 & 0.001 & -0.80 & $(-1.82,-0.48)$ \\
\hline Not having supplementary insurance & -0.15 & 0.002 & -0.83 & $(-1.36,-0.30)$ \\
\hline Inability to walk & -0.14 & 0.006 & -1.02 & $(-1.76,-0.29)$ \\
\hline Migraine & -0.12 & 0.013 & -0.76 & $(-1.37,-0.16)$ \\
\hline
\end{tabular}




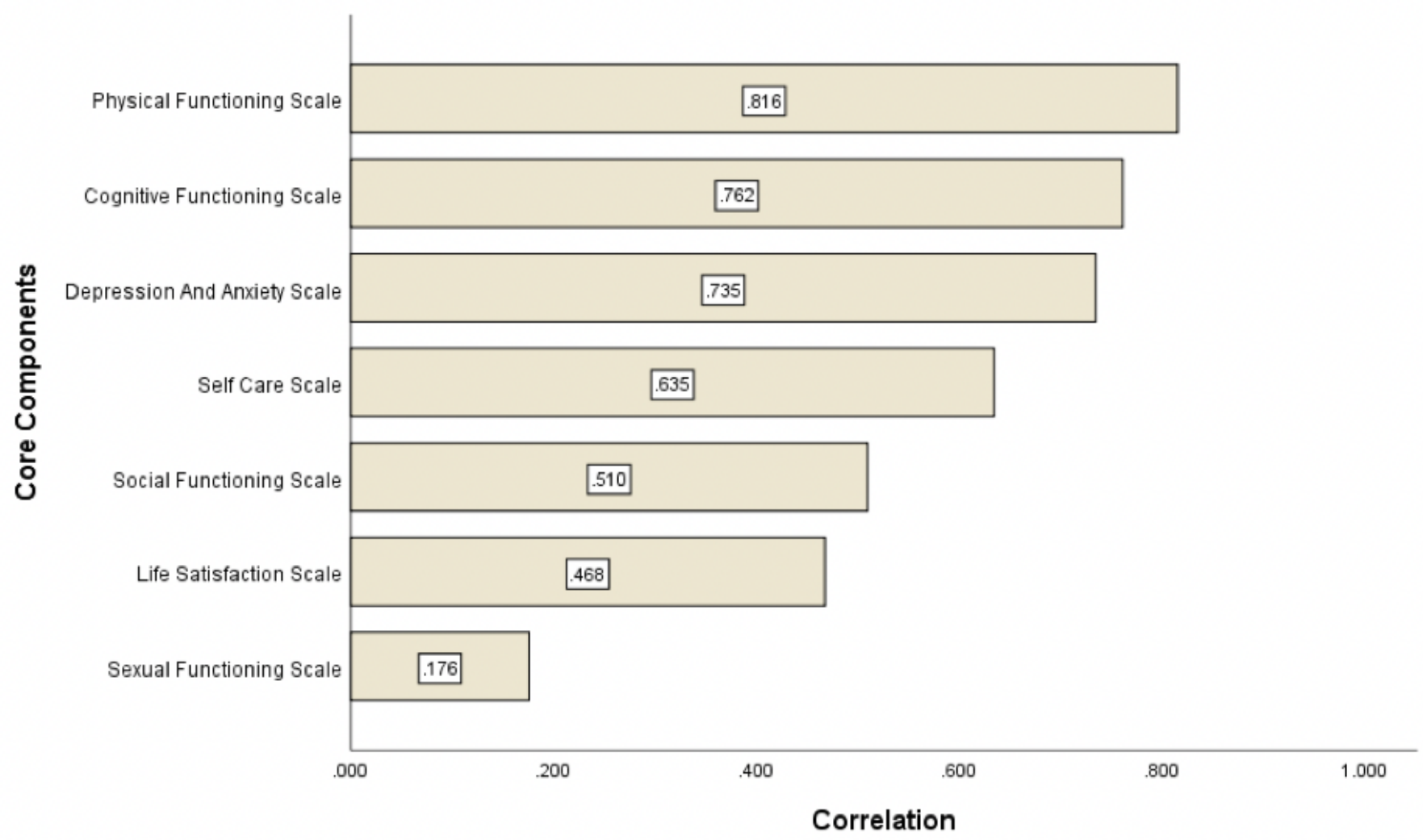

\section{Figure 1}

Correlation between the total score of core components of quality of life and each of its seven scales in the elders 


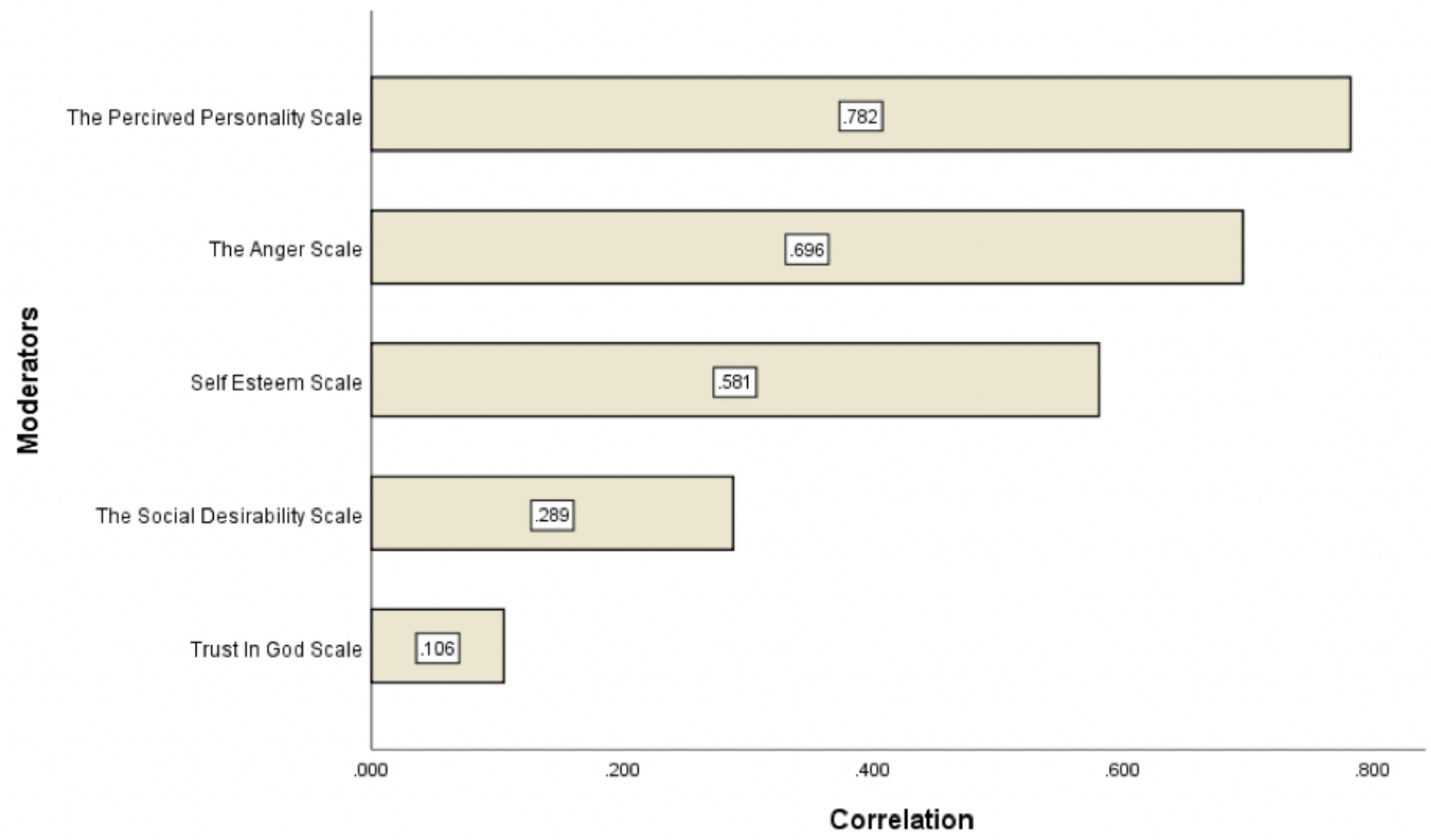

Figure 2

Correlation between the total score of moderator components of quality of life and each of the its five scales in the elders 